\title{
Development of a Scale to Measure Intrapersonal Psychological Empowerment to Participate in Local Tourism Development: Applying the Sociopolitical Control Scale Construct to Tourism (SPCS-T)
}

\author{
Eunseong Jeong ${ }^{1}$, Changsup Shim ${ }^{2, *(\mathbb{D}}$, Alan Dixon Brown ${ }^{3}$ and Shieun Lee ${ }^{4}$ \\ 1 Department of Tourism Management, Honam University, Gwangju 62399, Korea; eunseong@honam.ac.kr \\ 2 Department of Tourism Management, Gachon University, Seongnam-si 13120, Korea \\ 3 Department of Economics, Chonnam National University, Gwangju 61186, Korea; alan@jnu.ac.kr \\ 4 Korean Peninsula Tourism Center, Korea Tourism Organization, Wonju-si 26464, Korea; zoe9612@naver.com \\ * Correspondence: cshim@gachon.ac.kr
}

Citation: Jeong, E.; Shim, C.; Brown, A.D.; Lee, S. Development of a Scale to Measure Intrapersonal Psychological Empowerment to Participate in Local Tourism Development: Applying the Sociopolitical Control Scale Construct to Tourism (SPCS-T). Sustainability 2021, 13, 4057. https://doi.org/ $10.3390 /$ su13074057

Academic Editor: Salvador Anton Clavé

Received: 5 March 2021

Accepted: 2 April 2021

Published: 6 April 2021

Publisher's Note: MDPI stays neutral with regard to jurisdictional claims in published maps and institutional affiliations.

Copyright: (c) 2021 by the authors. Licensee MDPI, Basel, Switzerland. This article is an open access article distributed under the terms and conditions of the Creative Commons Attribution (CC BY) license (https:// creativecommons.org/licenses/by/ $4.0 /)$.

\begin{abstract}
Future tourism development must be guided by thoughtful and effective policies that represent the interests of a majority of community members to maximize the positive and minimize the negative impact on communities. Effective policies rely on the support of an engaged citizenry made up of residents who feel psychologically empowered. The primary purpose of this study was to develop a topic-specific measure of sociopolitical control in order to provide a reliable quantitative tool to evaluate tourism development in host communities. Confirmatory factor analysis yielded indices of an acceptable model fit that support the construct validity of a revised Sociopolitical Control Scale for Tourism (SPCS-T). The present study provides empirical evidence that policymakers and researchers interested in gauging support for future tourism policies can successfully apply the SPCS-T in the tourism context.
\end{abstract}

Keywords: intrapersonal psychological empowerment; sociopolitical control scale; sustainable tourism development

\section{Introduction}

Tourism development has long been recognized as a leading economic force and has the potential to play a role in rejuvenating host communities in tourist destinations. At the same time, mass tourism has been associated with unforeseen negative effects such as destruction of the ecological and socio-cultural environments of these tourism destinations [1]. Local citizen participation and empowerment are critical to alleviating the tension between the positive impact of tourism on economic development and its negative impact on tourism destinations.

In the last few decades, advances in information and communication technology have given people quicker and broader access to what is going on locally and globally and to all kinds of knowledge, making it more convenient for a greater number of people to participate in a wide range of local tourism policy-making processes. Indeed, changes in the sociopolitical and technological landscape have made citizen participation and empowerment a cornerstone of democratic decision-making in a number of contexts [2-5]. Tourism is one such area, where studies have emphasized the importance of empowering citizens to participate in the development of host communities as tourist destinations [6-8] and have recognized the importance of local infrastructure, enthusiasm, and hospitality to the full tourist experience of any particular tourist attraction.

Citizen participation and empowerment minimize conflict between host communities and tourism development and go a long way toward satisfying the demands of visiting tourists [9-11]. Encouraging local citizens to participate in tourism development serves to 
simultaneously enhance the local economy, preserve the socio-political culture, and protect the environment of host communities [12]. Empowered citizens are more likely to have increased pride in their city, to hold a positive perception of tourism, and to support local tourism projects, making better city ambassadors [13]. An empowered local citizenry in a host community can not only engage with tourism developers to make them aware of the community's unique set of traditions and values to be sustained and protected, but they can also proactively express their individual voices, experiences, and knowledge to inform tourism development. Citizen participation begins with awareness of tourism development policies, to which empowered citizens can then contribute creative ideas to affect development of tourism at the local level.

Although tourism scholars have taken an interest in the empowerment of host communities, these studies have solely focused on economic or political empowerment $[14,15]$, often addressing empowerment of the community by examining overall attitudes of residents and their involvement with tourism development without measuring empowerment at the individual level [16-18]. Zimmerman and Zahniser [19] did refine a sphere-specific measure of individual psychological empowerment (PE) in their sociopolitical control scale (SPCS). In the last two decades, the SPCS has been widely employed to test the relationship between intrapersonal components of psychological empowerment and citizen participation, mostly in community psychology studies [20-26]. Active citizen participation in tourism development has been found to enhance policy control (PC) and leadership competence (LC), two major intrapersonal components of psychological empowerment.

Hence, the primary purpose of this study is to develop a topic-specific measure of sociopolitical control in order to contribute a valid and reliable quantitative tool to measure individual empowerment to contribute to outcomes of tourism development in host communities. The study examines whether Zimmerman and Zahniser's SPCS can be modified for use in the tourism domain while maintaining its psychological rigor. The current study consists of three stages. First, previous studies on citizen participation, psychological empowerment, and sociopolitical control were extensively reviewed, particularly focusing on what conceptual elements construct these concepts. Second, a revised Sociopolitical Control Scale for Tourism (SPCS-T) was proposed and validated by experts consulting, pilot and major survey, and statistical analysis. Third and finally, theoretical and practical implications of the results were discussed to contribute to the local tourism development and the process of tourism policy formulation and implementation.

\section{Literature Review}

\subsection{Citizen Participation in the Host Community}

Collaborative policy-making among government agencies, businesses, and host communities is a critical feature of sustainable tourism development. Local initiatives to develop tourist attractions are of prime importance in developing local tourism so community involvement is critical to this end [27-29]. Increasingly, studies address host community attitudes toward tourism development, from examining development of community-based tourism generally [30-32] to more specifically analyzing host community reactions to the impact of tourism $[33,34]$. These studies argue that citizen participation in host communities is necessary to simultaneously pursue economic benefits while ensuring socio-cultural and environmental protection to host communities. Sustainable tourism requires a balance between economic outcomes and protection of the culture and environment in host communities, balancing the interests of various stakeholders such as local residents (i.e., host community), tourists, operators, and regulators [35].

Citizen participation should result in improving residents' comprehension of available public support for potential projects and policy-making priorities as well as better meeting stakeholder preferences and needs in developing community-based tourism. Citizen participation in tourism should create a network of businesses, developers, government groups, and local community groups and individuals in locales with booming tourism development [36]. Studies have identified indicators and models to measure sustainable 
community tourism development, pointing out conflicts between stakeholders, for example between indigenous and nonindigenous stakeholders and between local community members and pro-environmental groups in protecting natural resources [37-39]. Tourism scholars have encouraged local authorities to adopt policy goals for sustainable development that increase the involvement of local communities in participative, collaborative processes [40]. The diverse voices of stakeholders at tourism destinations need to be heard.

Research has highlighted citizen participation and community involvement by examining such diverse constructs as place attachment [41,42], community attachment $[43,44]$, community identity [45,46], and sense of community $[47,48]$. Using the concepts of citizen participation and community involvement can minimize preexisting and emerging conflicts between tourism development and host communities. In particular, community involvement in collaborative policy-making processes can mediate conflicts, for example, those between commercial tourism and land management agencies [49]. Community involvement allows governments and tourism developers to adjust tourism planning and development in a collaborative framework that takes into account the constantly changing economic, social, and environmental perceptions and opinions of residents within the community who are influenced by changing variables, such as the scale and nature of tourism development and related employment opportunities [50]. A feeling of community ownership in participatory planning has been shown to improve the outcomes of a project, leading to recommendations for stimulating community involvement and collaboration among stakeholders through (1) community ownership, (2) accessibility of planning and management resources, and (3) maintaining a broad stakeholder base by involving local NGOs [51]. In order to achieve active community involvement and citizen participation, governments and development authorities should be responsible for encouraging host communities to take action toward policy-making activities and for balancing the power and influence of elite groups and the public [52-54]. Technology can be used to assess community preferences through such means as Audience Response Systems or clickers, resulting in high levels of citizen engagement, participant satisfaction, and potential tourism development actions [55].

Furthermore, tourism research in the last few decades has witnessed the strong role of citizen participation in tourism development. Parallel to findings on tourism, community psychologists have claimed that psychologically empowered communities and citizens exert influence on their external sociopolitical circumstances and also act to improve their environments $[24,56,57]$. The PE of citizens is an indicator of the success of citizen participation of the host communities in policy-making processes, including tourism development.

\subsection{Psychological Empowerment and Sociopolitical Control}

Empowerment entails individual mastery over sociopolitical decisions by expanding a person's strength, competencies, and self-efficacy in decision-making activities in everyday life [23,58-60]. The concept of empowerment is said to occur when individuals gain greater control over their lives and participate in the lives of their primary and purposive groups [61,62]. The notion, therefore, simultaneously includes individual and organizational empowerment. Zimmerman [63] claimed that the former emphasizes individuals' self-efficacy and control in sociopolitical circumstances while the latter highlights individuals' collaboration within an organization. Empowerment broadly refers to an individual's act of empowering others while psychological empowerment (PE) represents the internal state of an individual being empowered [64].

PE involves the individual, the individual's active engagement in the community, and the individual's direct realization of sociopolitical circumstances and a self-perception of competence [65]. Zimmerman theorized that interactional, behavioral, and intrapersonal aspects of PE are all interrelated. The interactional component of PE represents awareness and understanding of the political situation; the behavioral component refers to purposive actions to affect outcomes; and the intrapersonal component includes individual compe- 
tence, efficacy, and mastery [66,67]. Among the three components of PE, the intrapersonal element most strongly indicates an individual's perceived capacity to control any particular sociopolitical context [68].

Within the last few decades, the SPCS has been widely utilized by community psychologists to measure the intrapersonal component of PE, reflecting how strongly an individual believes in his or her ability and efficacy in sociopolitical contexts [18,22,69-73]. The SPCS measures two primary dimensions of the intrapersonal component of an individual's psychological empowerment: leadership competence (LC) and policy control (PC). The two dimensions are the primary latent structures of SPCS: PC refers to individuals' beliefs that one can influence the political circumstances, while LC alludes to one's sense of leadership efficacy [67]. These have been empirically shown to be two latent variables in the SPCS, which is considered to be a "sphere-specific" measure of perceived control [70].

The SPCS has been employed as a measure to assess public policies in diverse areas, such as natural resource decision-making [71], public health programs [26], ecological resilience [74], youth programs [75], and social welfare [76]. Scholars have also studied the SPCS as a measurement tool in order to improve its internal consistency. Peterson et al. [67] rephrased the scale's two negatively worded items so all statements were positively worded and confirmatory factor analysis showed the revised scale (SPCS-R) to better support the scale's two-factor structure (LC and PC) and found subscales of the SPCS-R to be reliable. Tourism studies have been interested in PE and SPCS, mainly focusing on the PE of employees in the tourism industry [58,77].

The roles of communities and local residents of tourist destinations have been critical elements leading to sustainable and positive outcomes in tourism development. Many studies, therefore, have demonstrated factors affecting resident attitudes toward tourism development [78-81]. While these studies have examined resident perceptions and satisfaction toward tourism development, few tourism studies have directly identified individual levels of resident empowerment toward tourism development in host communities.

\section{Research Method}

\subsection{Generation of Scale Items}

In order to overcome measurement error, the development of survey questions is critical because poor questionnaire wording and construction leads to measurement error [82]. Therefore, survey questions should use words that are consistent and valid measures of the constructs the study wants to examine [83]. Researchers seeking to develop a scale should first engage in an appropriate literature review, consult experts, and conduct preor pilot tests in order to minimize measurement error. The scale items used in this study reflect intrapersonal components of PE. Our SPCS-T is aimed to measure local tourism development and was generated from a comprehensive review of the literature related to the original SPCS items. The pool of items was created from two focus groups of current residents living in the research area. Tourism studies to develop scales have followed Churchill's [84] recommendation to use individual and group interviews to generate items to include on a scale [85-88].

Additionally, in the present study, a jury of five tourism experts in South Korea reviewed the set of 17 generated items to judge content validity and clarity of the rephrased items in the SPCS-T. The purpose of the expert panel was to avoid coverage error by determining whether the SPCS-T correctly reflects sociopolitical circumstances relevant to local tourism development in the study area. A 5-point Likert scale was used for this study, where 1 denoted "strongly disagree" and 5 represented "strongly agree". Participants were surveyed to evaluate their level of SPCS-T toward local tourism development using a set of diverse statements in the above form.

The 17 items enumerated in previous studies on the SPCS $[25,63,67,70,71,89]$ were used for the present SPCS-T as intrapersonal components of psychological empowerment toward local tourism development. Eight statements on LC were directly adopted from the original SPCS scale: "I am often a leader in groups", "I would prefer to be a leader 
rather than a follower", "I would rather have a leadership role when I am involved in a group project", "I can usually organize people to get things done", "Other people usually follow my idea", "I find it very easy to talk in front of a group", "I like to work on solving a problem myself rather than wait and see if someone else will deal with it", and "I like trying new things that are challenging to me".

Nine statements on PC from the original SPCS scale were rephrased for the tourism context for our Tourism Policy Control(TPC): "I enjoy political participation because I want to have as much say as possible in influencing the tourism department of my city", "A person like me can really understand what is going on with the tourism department of my city", "I feel like I have a pretty good understanding of the important tourism development decision making processes in my city", "People like me are generally well qualified to participate in the tourism development decision making process in my city", "It makes a difference who I support for local tourism development because my support will represent my interest", "There are plenty of ways for people like me to have a say in what the local tourism development agency does", "It is important to me that I actively participate in local tourism development issues", "Most local tourism development agent officials in the city would listen to me", and "Local tourism development is important to support". Table 1 presents definitions and sources of major constructs in this study.

Table 1. Major Definitions of Constructs for the Measurement Model.

\begin{tabular}{ccc}
\hline Construct & Definition & Relevant Literature \\
\hline \multirow{3}{*}{ Sociopolitical Control } & Individuals' belief about their & Itzhaky \& York, 2001; \\
Scale for Tourism & abilities and efficacy in social and & Martinez et al., 2017 [90]; \\
& political circumstance toward & Smith \& Propst, 2001; \\
& tourism development & Zimmerman \& Zahniser, 1991; \\
& Individuals' skills, which may & Peterson et al., 2006; Opara \\
& include organizing others for & et al., 2020 [91]; Smith \& \\
Leadership Competence & common goals and expressing & Propst, 2001; Zimmerman \& \\
& their voices in front of others or & Zahniser, 1991; \\
& groups & Holden, Evans, Hinnant, \& \\
& A sense of control over one's life & Messeri, 2005; Jeong et al., \\
& toward policy-making activities & 2018 [92]; Smith \& Propst, \\
Tourism Policy Control & 2001; Zimmerman \& \\
& in tourism development & Zahniser, 1991 \\
\hline
\end{tabular}

\subsection{Sample and Data Collection Empowerment}

The study was conducted in the city of Mokpo, located in the southwestern part of South Korea. The study selected the city as a research area because the city has an active locally based small-scale tourism industry with a focus on cultural and farm tourism activities with active citizen participation and empowerment. Local community support and participation are significant elements in successfully accomplishing local and smallscale tourism development. Most studies related to SPCS have tested it with American cases and community programs; therefore, a pilot study was necessary in order to test whether the rephrased scale items could effectively reflect tourism contexts and consider them in different sociopolitical settings. Before conducting the major survey, a pilot study was conducted with 67 residents of the city to minimize measurement errors in the two dimensions of the SPCS-T (TLC and TPC). The tested scale for these two dimensions of the SPCS-T demonstrated acceptable reliability ranging from $\alpha=0.84$ to $\alpha=0.91$.

This study measured residents of the city who were more than 19 years old and who had lived in the city since 2019. The age of 19 was chosen because that is the age at which individuals are legally eligible to vote in South Korea, so the population group was qualified to actually engage in sociopolitical activities in the region. Data was collected through a city household survey under a part of the city's Tourism Comprehensive Plan. As of 2019, the total number of households in the city was approximately 101,609; therefore, 
the required sample size was approximately 1040 samples for the study, plus or minus 3\% for sampling error [82]. Based on household mailing addresses, every 38th household was selected for the sample, and a total of 1040 mail surveys were sent through a systematic sampling process [88]. Many studies claim that in order to implement confirmatory factor analysis (CFA), it is necessary to have a large number sample size because of the sensitivity to sample size in the model [93]. However, there is little consensus on recommended sample size. Nevertheless, Garver and Mentzer [94] proposed that a sample size of 200 or above is critical for conducting CFA and structural equation modeling.

\section{Results}

\subsection{Sample Characteristics}

In total, 547 city residents completed the household survey (response rate: $52.6 \%$ ), and the citywide margin of error was $2.87 \%$ with a $95 \%$ confidence level. The final sample consisted of $50.4 \%$ females and $49.6 \%$ males. The average age of respondents was 45 years and their average annual household income was USD 17,830. The majority of the survey participants $(87.2 \%)$ were born in the research area. Additionally, the study asked survey participants who were not born in the study site how long they had lived there; as a result, the average year of living in the city in which they were born was 13 years. Less than half of the survey participants $(43.7 \%)$ had more than a high school education.

\subsection{Purification of Scale Items}

There were three steps for scale purification of the 17 items on the SPCS-T. Before testing the reliability and validity of a scale, parametric statistics are ideally conducted under the assumption of the normal distribution. Therefore, for the SPCS-T, our study transformed the values of items to their respective z-scores, all with a mean of zero and standard deviation of one [95]. The z-score is a standard score that not only allows calculation of the probability of a score fitting the normal distribution but also permits the identification of univariate outliers [96,97].

The second step in scale purification was to conduct Cronbach's alpha test. The test estimated reliability of the measured items in terms of internal consistency by examining correlations between items [98,99]. The alpha values of all items ranged from 0.936 to 0.940 , which exceeded the recommended standard 0.7 [100]. The third step in scale purification was to perform exploratory factor analysis (EFA). EFA is recommended to identify the hypothetical factor structure of a construct. In other words, EFA is used to demonstrate the dimensionality of a modified structure of a construct when the items of latent structure are modified or rephrased not only from one discipline to another discipline but also from one population to another population $[101,102]$. EFA, through principal component factor analysis, of the 17 items utilizing Varimax and Oblinin rotations was conducted to demonstrate the dimensionality of SPCS-T, with the two factors explaining $71.8 \%$ of variance. The Kaiser-Meyer-Olkin (KMO) measure of sampling adequacy was 0.948, which is above the recommended value of 0.6 [103], and Bartlett's Test of Sphericity was statistically significant $\left(\chi^{2}(136)=5240.84, p<0.001\right)$. Based on the EFA results (Table 2), one item, "Local tourism development is important to support", was removed because the item failed to meet the minimum criterion of having a primary factor loading of 0.5 [104]. The resulting hypothetical structure of the construct of this study is depicted in Figure 1. The validation of the SPCS-T was provided to conduct CFA. 
Table 2. Results of Exploratory Factor Analysis for the Initial Measurement Model.

\begin{tabular}{|c|c|c|c|c|c|}
\hline Construct & Item & Description & Factor Loading & Variance $(\%)$ & $\alpha$ \\
\hline \multirow[t]{9}{*}{$\begin{array}{l}\text { Leadership } \\
\text { Competence }\end{array}$} & & & & 36.163 & \\
\hline & LC1 & I am often a leader in groups. & 0.816 & & 0.937 \\
\hline & LC2 & $\begin{array}{l}\text { I would prefer to be a leader rather than } \\
\text { a follower. }\end{array}$ & 0.809 & & 0.937 \\
\hline & LC3 & $\begin{array}{l}\text { I would rather have a leadership role when I } \\
\text { am involved in a group project. }\end{array}$ & 0.852 & & 0.937 \\
\hline & LC4 & $\begin{array}{l}\text { I can usually organize people to get } \\
\text { things done. }\end{array}$ & 0.873 & & 0.936 \\
\hline & LC5 & Other people usually follow my idea. & 0.844 & & 0.936 \\
\hline & LC6 & $\begin{array}{l}\text { I find it very easy to talk in front of a group. } \\
\text { I like to work on solving a problem myself }\end{array}$ & 0.840 & & 0.937 \\
\hline & LC7 & $\begin{array}{l}\text { rather than wait and see if someone else will } \\
\text { deal with it. }\end{array}$ & 0.808 & & 0.937 \\
\hline & LC8 & $\begin{array}{l}\text { I like trying new things that are challenging } \\
\text { to me. }\end{array}$ & 0.801 & & 0.937 \\
\hline \multirow[t]{10}{*}{$\begin{array}{c}\text { Tourism } \\
\text { Policy Control }\end{array}$} & & & & 35.621 & \\
\hline & TPC1 & $\begin{array}{c}\text { I enjoy political participation because I want } \\
\text { to have as much of a say as possible in } \\
\text { influencing the tourism department of } \\
\text { my city. }\end{array}$ & & 0.788 & 0.938 \\
\hline & TPC2 & $\begin{array}{l}\text { A person like me can really understand what } \\
\text { is going on with the tourism department of } \\
\text { my city. }\end{array}$ & & 0.852 & 0.937 \\
\hline & TPC3 & $\begin{array}{l}\text { I feel like I have a pretty good understanding } \\
\text { of the important tourism development } \\
\text { decision making processes in my city. }\end{array}$ & & 0.828 & 0.937 \\
\hline & TPC4 & $\begin{array}{l}\text { People like me are generally well qualified to } \\
\text { participate in the tourism development } \\
\text { decision making process in my city. }\end{array}$ & & 0.786 & 0.936 \\
\hline & TPC5 & $\begin{array}{l}\text { It makes a difference who I support for local } \\
\text { tourism development because my support } \\
\text { will represent my interest. }\end{array}$ & & 0.823 & 0.936 \\
\hline & TPC6 & $\begin{array}{c}\text { There are plenty of ways for people like me } \\
\text { to have a say in what the local tourism } \\
\text { development agency does. }\end{array}$ & & 0.820 & 0.937 \\
\hline & ТPC7 & $\begin{array}{c}\text { It is important to me that I actively } \\
\text { participate in local tourism } \\
\text { development issues. }\end{array}$ & & 0.785 & 0.936 \\
\hline & ТРС8 & $\begin{array}{l}\text { Most local tourism development agency } \\
\text { officials in the city would listen to me. }\end{array}$ & & 0.789 & 0.940 \\
\hline & ТPC9 & $\begin{array}{l}\text { Local tourism development is important } \\
\text { to support. }\end{array}$ & & 0.598 & 0.939 \\
\hline
\end{tabular}




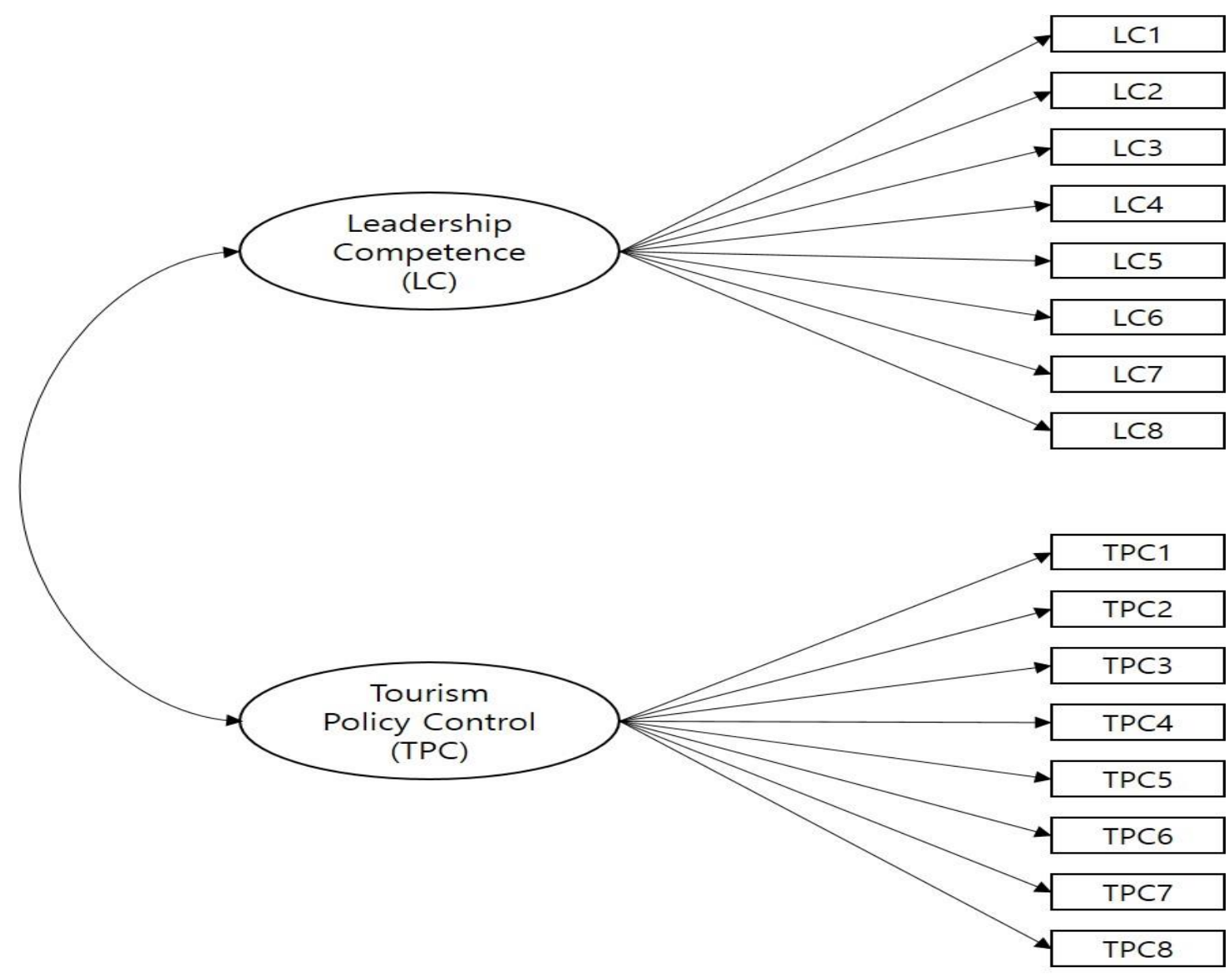

Figure 1. Proposed Measurement Model of the Structure of Sociopolitical Control Scale for Tourism (SPCS-T). Note: LC refers to leadership competence; and TPC represents tourism policy control. The observed variables were tested based on the measurement by employing their factor loadings and their error term. The error term was omitted in this figure.

\subsection{Validity and Reliability of the SPCS-T}

CFA was used to evaluate the psychometric properties of our scale. Harrington [105] argued that CFA can examine construct validity and whether a scale is consistent or invariant across group, population, or time. She also recommended CFA to confirm the factor structure to test whether the same construct structure can be identified in a new sample. Both EFA and CFA identify the factor structure that explains variation and covariation among a series of observed variables [106]. EFA is a statistical technique to establish a primary model that fits the data while CFA validates the fit of that data and tests a predetermined model [107].

The Maximum Likelihood (ML) fitting function was used in the CFA to estimate each of the remaining 16 items in the SPCS-T measurement model, utilizing AMOS 25 to examine the overall fit of the SPCS-T model. Chi-square $\left(\chi^{2}\right)$ to the degree of freedom ratio (i.e., CMIN/DF) is the minimum discrepancy divided by its degree of freedom. Carmines and McIver [106] (p. 80) suggested that "the ratio of CMIN/DF in the range of 2 to 1 is an adequate fit between the hypothetical model and the sample data." The goodness of fit index (GFI) was formulated by Jőreskog and Sóbom [108] for ML and unweighted least squares in which a value of 1 indicates a perfect fit. The Tucker-Lewis index (TLI) represents the non-normalized fit index (NNFI) and the context of analysis of moment structures [109]. The comparative fit index (CFI) identifies the relative noncentrality of index (RNI), which measures the proportionate improvement in fit by comparing the target model with the independent model [110]. Both TLI and CFI values close to 1 indicate a 
perfect fit. The root mean square error of approximation (RMSEA) measures the degree to which the analyzed data approximates the population covariance matrix [111]. Browne and Cudeck [112] suggested that a value of less than 0.05 is identical to a close fit of the model in terms of the degree of freedom. Based on Kline's [100] suggestions, the proposed CFA goodness-of-fit indices and their ranges of this study are displayed in Table 3.

Table 3. Proposed Goodness-of-Fit Indices for Confirmatory Factor Analysis.

\begin{tabular}{cc}
\hline Goodness-of-Fit Indices & Proposed Range of Good Model Fit \\
\hline Chi-square $\left(\chi^{2}\right)$ to the degree of freedom ratio & $<5.0$ \\
(CMIN/DF) & $>0.90$ \\
Goodness of fit index (GFI) & $>0.90$ \\
Tucker-Lewis index (TLI) & $>0.90$ \\
Comparative Fit Index (CFI) & $<0.50$ \\
Root mean square error of approximation & \\
\hline
\end{tabular}

Data Source: Kline (2005).

Results of the CFA showed that the hypothetical SPCS-T measurement model fit the data. Even though the two scales (LC and TPC) were hypothesized to be independent, correlation coefficients were calculated. The Chi-square value for the overall model fit was significant, $\chi^{2}(103)=389.79, p<0.001$, indicating good model fit. Examination of these indices showed acceptable model fit with $\mathrm{CMIN} / \mathrm{DF}=3.784, \mathrm{GFI}=0.942, \mathrm{TLI}=0.932$, $\mathrm{CFI}=0.942$, and RMSEA $=0.090$. Most of the model fit indices met the recommended fit values except for the value of RMSEA. Modification indices suggest freeing the covariance between two error terms [113]. The study, therefore, re-conducted CFA after obtaining the modification indices; as a result, a subsequent model was found to have better fit to the constrained model, $\chi^{2}(84)=146.49, p<0.001, \mathrm{CMIN} / \mathrm{DF}=1.744, \mathrm{GFI}=0.951, \mathrm{TLI}=0.982$, $\mathrm{CFI}=0.987$, and RMSEA $=0.046$. Given the significant improvement in overall model fit, allowing the two error covariances was considered the better model.

The composite reliability test confirms reliability of a scale construct by utilizing item loadings obtained within a nomological network [114]. A nomological network refers to the basic feature of a construct by providing evidence of observable manifestations and the interrelationships among constructs [56]. Composite reliability of the two SPCS-T scales (LC and TPC) ranged from 0.955 (LC) and 0.950 (TPC), which indicated good internal consistency of the model $(>0.70)$. Average variance extracted (AVE) was utilized to test discriminant validity to show that measurement items in the SPCS-T not only have method variance but are also pure measures of discrete traits [115]. The AVE of the two constructs (LC and TPC) exceeded the recommended standard of 0.50. Table 4 presents the results of the CFA for the measurement model. Lastly, standardized factor loadings for items ranged from 0.692 to 0.883 . The ideal factor loading is greater than 0.70 [116], but studies generally suggest that at least 0.50 for standardized factor loading is generally acceptable [100]. 
Table 4. Results of Confirmatory Factor Analysis of Sociopolitical Control Scale for Tourism (SPCS-T).

\begin{tabular}{|c|c|c|c|c|c|}
\hline Construct & Item & Description & $\begin{array}{l}\text { Standardized } \\
\text { Factor Loading }\end{array}$ & $\begin{array}{l}\text { Composite } \\
\text { Reliability }\end{array}$ & AVE \\
\hline \multirow{9}{*}{$\begin{array}{l}\text { Leadership } \\
\text { Competence }\end{array}$} & & & & 0.956 & 0.729 \\
\hline & LC1 & I am often a leader in groups. & 0.805 & & \\
\hline & LC2 & $\begin{array}{l}\text { I would prefer to be a leader rather than } \\
\text { a follower. }\end{array}$ & 0.813 & & \\
\hline & LC3 & $\begin{array}{l}\text { I would rather have a leadership role when I } \\
\text { am involved in a group project. }\end{array}$ & 0.835 & & \\
\hline & LC4 & $\begin{array}{l}\text { I can usually organize people to get } \\
\text { things done. }\end{array}$ & 0.883 & & \\
\hline & LC5 & Other people usually follow my idea. & 0.876 & & \\
\hline & LC6 & $\begin{array}{l}\text { I find it very easy to talk in front of a group. } \\
\text { I like to work on solving a problem myself }\end{array}$ & 0.863 & & \\
\hline & LC7 & $\begin{array}{l}\text { rather than wait and see if someone else will } \\
\text { deal with it. }\end{array}$ & 0.839 & & \\
\hline & LC8 & $\begin{array}{l}\text { I like trying new things that are challenging } \\
\text { to me. }\end{array}$ & 0.815 & & \\
\hline \multirow[t]{9}{*}{$\begin{array}{l}\text { Tourism } \\
\text { Policy Control }\end{array}$} & & & & 0.950 & 0.705 \\
\hline & TPC1 & $\begin{array}{c}\text { I enjoy political participation because I want } \\
\text { to have as much of a say as possible in } \\
\text { influencing the tourism department of } \\
\text { my city. }\end{array}$ & 0.778 & & \\
\hline & TPC2 & $\begin{array}{l}\text { A person like me can really understand what } \\
\text { is going on with the tourism department of } \\
\text { my city. }\end{array}$ & 0.820 & & \\
\hline & TPC3 & $\begin{array}{l}\text { I feel like I have a pretty good understanding } \\
\text { of the important tourism development } \\
\text { decision making processes in my city. }\end{array}$ & 0.817 & & \\
\hline & TPC4 & $\begin{array}{l}\text { People like me are generally well qualified to } \\
\text { participate in the tourism development } \\
\text { decision making process in my city. }\end{array}$ & 0.816 & & \\
\hline & TPC5 & $\begin{array}{l}\text { It makes a difference who I support for local } \\
\text { tourism development because my support } \\
\text { will represent my interest. }\end{array}$ & 0.859 & & \\
\hline & TPC6 & $\begin{array}{c}\text { There are plenty of ways for people like me } \\
\text { to have a say in what the local tourism } \\
\text { development agency does. }\end{array}$ & 0.852 & & \\
\hline & TPC7 & $\begin{array}{l}\text { It is important to me that I actively } \\
\text { participate in local tourism } \\
\text { development issues. }\end{array}$ & 0.826 & & \\
\hline & TPC8 & $\begin{array}{l}\text { Most local tourism development agency } \\
\text { officials in the city would listen to me. }\end{array}$ & 0.692 & & \\
\hline
\end{tabular}

\section{Discussion and Conclusions}

The concept of citizen participation and empowerment has become a significant area of study in tourism with the growing emphasis on community-based and sustainable tourism practices. Active, voluntary citizen participation enhances policy control and leadership competence, which are two key ingredients of psychological empowerment. Psychologically empowered individuals can contribute to the development of creative solutions in policy-making processes, including local tourism development. Citizen support and motivation to participate in tourism development come from various sources, beginning with an awareness of policies and programs. It is, therefore, very important to evaluate community assets, which create momentum to drive forward policy and program goals.

Two correlates of momentum are an individual's psychological empowerment and participation in the implementation of tourism development in host communities. In 
this respect, the sociopolitical control scale (SPCS) has been widely employed in the last few decades to investigate the relationship between the intrapersonal component of psychological empowerment (PE) and citizen participation in developing public policies and implementing and managing programs. Public policy and regional development research have measured the psychological empowerment of local residents using the SPCS scale and, based on the results, have suggested measures to induce citizen participation. However, there is a gap in investigating this relationship in tourism studies, suggesting the need for direct measurement of the psychological empowerment of local residents as a factor that induces citizen participation in tourism development. The reason for this is the relatively limited role participation of local residents has traditionally played in establishing tourism development policies compared to other public and regional development policies.

Tourism research has found that strong ties to the community empower individuals to take part in policy-making for local-based tourism development [30]. Tourism development has also been acknowledged to be a leading economic force and has the potential to contribute to the rejuvenation of the economies of nations as well as local communities. At the same time, mass tourism is often associated with negative impacts such as the destruction of natural, social, and cultural features of host community tourist destinations [26]. Thus, citizen participation and empowerment are critical factors in minimizing the tension between economic growth and protection of tourism resources. This has encouraged tourism scholars to study the issues of host community involvement and citizen participation in tourism. The tourism industry generally and policymakers at all levels should take great interest in knowing what is needed to empower citizen participation, whether or not residents see themselves as participants, and what these participants are doing to remain actively involved. Citizen input can improve the quality of development initiatives and provide support for tourism policy, thereby creating better tourist experiences based on local support and pride in tourist destinations.

Against this background, the study examined whether the SPCS could be modified to be useful in the tourism domain (SPCS-T) as a valid and reliable quantitative scale to measure individual psychological empowerment to participate in tourism development. CFA showed evidence of the new model's reliability as an accurate and precise measurement instrument after one item in the tourism policy control (TPC9) subscale was deleted from the full measurement model. The value of standardized factor loadings and model-fit indices demonstrated that the model fit the recommended requirements for scale construction. The results also establish discriminant validity of the model by showing the variance between indicators that specifically explain the variance in the construct [117] (p. 1099).

The present study has several implications for citizen participation and community involvement in the tourism domain. It found that the SPCS could be modified for use in the tourism domain. As a result, the SPCS-T can be used to assess a citizen's level of psychological empowerment in policy-making and tourism development. The study expects the construct to provide an improved measure by which to understand the level of perceived control and self-efficacy in contributing to tourism policy-making and development. For this reason, the study emphasizes the significance of sociopolitical indicators of success. Tourism is a system with various stakeholders in host communities all contributing to tourism development, but success is mainly evaluated with economic indices. Social indices, such as the level of citizen participation and empowerment, also represent important measures for successful tourism development beyond ultimate contribution to the community's economic growth. Hence, in the context of tourism development, psychological empowerment of local residents to participate in tourism development results in closer community networks and increased satisfaction of locals and tourists alike. The tourism industry can deliver on the promise of memorable tourism attractions when residents of host communities maintain an empowered role within the tourism policy-making and development process. In summary, the present study provides a SPCS-T scale for tourism researchers and policymakers to use to measure sociopolitical outcomes of tourism development with a focus on community-based programs and initiatives. 
The items of the major construct of this study, the SPCS, were reworded to be appropriate to the tourism domain. The rephrased items of the TPC were found to be problematic in terms of citizen engagement in local tourism development. One item of the TPC was removed because of low factor loading, which indicated issues of reliability and validity of the scale. As a result, the study confirmed the validity of a new SPCS-T for the tourism domain and tested it in different sociopolitical settings. Meanwhile, it is recommended that future study more clearly reflect a research area's particular sociopolitical circumstances in order to develop the SPCS-T as a standardized construct of the intrapersonal component of psychological empowerment toward tourism development. In particular, an autonomous local government system has taken root throughout Korea, with tourism development widely recognized as a primary means for regional revitalization. In order to pursue sustainable tourism development, it is necessary to develop and implement policies and programs that enhance the empowerment of local residents using the SPCS-T, through which their psychological empowerment can be measured. Next, in order to use the SPCS-T as a more generalized construct in the tourism domain, it is necessary for future studies to test the construct across a wide range of different communities.

Lastly, individual psychological empowerment is internal and is affected by constant changes in an individual's life and environment; hence, it is dynamic and ever-changing. Consequently, research needs to assess individual internal changes in residents of different communities over time. In order to pursue sustainable tourism development, the study emphasized the psychological empowerment of local residents and suggested an instrument for its measurement. However, since the SPCS-T measures the intrapersonal component of psychological empowerment, it is necessary to develop a scale that can measure its interpersonal component as an additional means of measuring the psychological empowerment of local residents. The SPCS-T was developed within the limited temporal and spatial scope of a specific period of residence in one city, Mokpo. As a consequence, the study is unable to capture temporal changes to psychological empowerment. Since the importance of longitudinal data has been recognized, applying the latent growth model (LGM) will be an effective analytical tool in future studies to examine individual social and psychological changes over time. This in turn will help the SPCS-T maintain and improve its strength as a model.

The current results provide some practical implications for local tourism development and the process of tourism policy formation and implementation. Despite a current lack of actual resident involvement in local tourism development, the sociopolitical control exercised by residents, including their leadership competence and extent of control over policy, is a valid construct that will potentially contribute to sustainable management of tourist destinations. Accordingly, local governments and destination management organizations should make a conscious effort to increase opportunities for residents to more actively participate in change of their local community through tourism. Furthermore, host communities should provide educational programs and job opportunities to support local residents in becoming leaders and self-assured actors able to more actively design the future of their regions as tourist destinations.

Author Contributions: Conceptualization, E.J., C.S. and A.D.B.; methodology, E.J. and A.D.B.; validation, E.J., C.S. and A.D.B.; formal analysis, S.L.; writing-original draft preparation, E.J.; writing-review and editing, C.S.; visualization, S.L.; supervision, E.J. All authors have read and agreed to the published version of the manuscript.

Funding: This research received no external funding.

Institutional Review Board Statement: Not applicable.

Informed Consent Statement: Not applicable. 


\section{Data Availability Statement: Not applicable.}

Conflicts of Interest: The authors declare no conflict of interest.

\section{References}

1. Chapman, A.; Speake, J. Regeneration in a mass-tourism resort: The changing fortunes of Bugibba, Malta. Tour. Manag. 2011, 32, 482-491. [CrossRef]

2. Chamber, S. Deliberative democratic theory. Annu. Rev. Polit. Sci. (Palo Alto) 2003, 6, 307-326. [CrossRef]

3. Manzo, L.; Perkins, D.D. Finding common ground: The importance of place attachment to community participation and planning. J. Plan. Lit. 2006, 20, 335-350. [CrossRef]

4. Reddel, T.; Woolcock, G. From consultation to participatory governance? A critical review of citizen engagement strategies in Queensland. Aust. J. Public Adm. 2004, 63, 75-87. [CrossRef]

5. Umbach, G.; Wishnoff, D. Strategic self-orientalism: Urban planning policies and the shaping of New York City's Chinatown, 1950-2005. J. Plan. Hist. 2008, 7, 214-238. [CrossRef]

6. Allen, L.R.; Long, P.T.; Perdue, R.R.; Kieselbach, S. The impact of tourism development on residents' perceptions of community Life. J. Travel Res. 1988, 27, 16-21. [CrossRef]

7. Reed, M.G. Power relations and community-based tourism. Ann. Tour. Res. 1997, 24, 566-591. [CrossRef]

8. Tosun, C. Stages in the emergence of a participatory tourism development approach in the developing world. Geoforum 2005, 36, 333-352. [CrossRef]

9. Liu, Z. Sustainable tourism development: A critique. J. Sustain. Tour. 2003, 11, 459-475. [CrossRef]

10. Pérez, E.A.; Nadal, J.R. Host community perceptions: A cluster analysis. Ann. Tour. Res. 2005, 32, 925-941. [CrossRef]

11. Neupane, K.; Shim, C. Paragliding tourism and cultural sustainability: A case study of Pokhara. Int. J. Tour. Hosp. Res. 2019, 33, 49-65. [CrossRef]

12. Lansing, P.; De Vries, P. Sustainable tourism: Ethical alternative or marketing ploy. J. Bus. Ethics 2007, 72, 77-85. [CrossRef]

13. Nijs, V. Resident Attitudes towards Tourism in Bruges. 2016. Available online: https://scholar.googleusercontent.com/scholar?q= cache:DltNRKPIeiEJ:scholar.google.com/+Resident+Attitudes+Towards+Tourism+in+Bruges\&hl=ko\&as_sdt=0,5\&as_vis=1 (accessed on 28 March 2021).

14. Cole, S. Information and empowermentL The keys to achieving sustainable tourism. J. Sustain. Tour. 2006, 14, 629-644. [CrossRef]

15. Scheyvens, R. Ecotourism and the empowerment of local communties. Tour. Manag. 1999, 20, 245-249. [CrossRef]

16. Manyara, G.; Johnes, E. Community-based tourism enterprises development in Kenya: An exploration of their potential as avenues of poverty reduction. J. Sustain. Tour. 2007, 15, 628-644. [CrossRef]

17. Mitchell, R.E.; Reid, D.G. Community integration: Island tourism in Peru. Ann. Tour. Res. 2001, 28, 113-139. [CrossRef]

18. Simpson, M. Community benefit tourism initiative- A conceptual oxymoron? Tour. Manag. 2008, 29, 1-18. [CrossRef]

19. Zimmerman, M.A.; Zahniser, J.H. Refinements of sphere-specific measures of perceived control: Development of a sociopolitical control scale. J. Community Psychol. 1991, 19, 189-204. [CrossRef]

20. Christens, B.D.; Peterson, N.A.; Speer, P.W. Community participation and psychological empowerment: Testing reciprocal cauality using a cross-lagged panel design and latent construct. Health Educ. Behav. 2011, 38, 339-347. [CrossRef]

21. Holden, D.J.; Evans, W.D.; Hinnant, L.W.; Messeri, P. Modeling psychological empowerment among youth involved in local tobacco control efforts. Health Educ. Behav. 2005, 32, 264-278. [CrossRef] [PubMed]

22. Itzhaky, H.; York, A.S. Sociopolitical control and empowerment: An extended replication. J. Community Psychol. 2000, 28, 407-415. [CrossRef]

23. Itzhaky, H.; York, A.S. Leadership competence and political control: The influential factors. J. Community Psychol. 2003, 31, 371-381. [CrossRef]

24. Perkins, D.D.; Zimmerman, M.A. Empowerment theory, research, and application. Am. J. Community Psychol. 1995, 23, 569-579. [CrossRef] [PubMed]

25. Zimmerman, M.A.; Israel, B.A.; Schulz, A.; Checkoway, B. Further exploration in empowerment theory: An empirical analysis of psychological empowerment. Am. J. Community Psychol. 1992, 20, 707-727. [CrossRef]

26. Zimmerman, M.A.; Ramírez-Valles, J.; Maton, K.I. Resilience among urban African American male adolescents: A study of the protective effects of sociopolitical control on their mental health. Am. J. Community Psychol. 1999, 27, 733-751. [CrossRef] [PubMed]

27. Boley, B.B.; Nickerson, N.P.; Bosak, K. Measuring geotourism: Developing and testing the geograveler tendency scale (GTS). J. Travel Res. 2011, 50, 567-578. [CrossRef]

28. Dredge, D. Policy networks and the local organisation of tourism. Tour. Manag. 2006, 27, 269-280. [CrossRef]

29. Prentice, R. Community-driven tourism planning and residents' preference. Tour. Manag. 1993, 14, 218-227. [CrossRef]

30. Blackstock, K. A critical look at community based tourism. Community Dev. J. 2005, 40, 39-49. [CrossRef]

31. Novelli, M.; Gebhardt, K. Community-based tourism in Namibia: 'Reality show' or 'Widow dressing'? Curr. Issues Tour. 2007, 10, 443-479. [CrossRef]

32. Wearing, S.; McDonald, M. The development of community-based tourism: Re-thinking the relationship between tour operators and development agents as intermediaries in rural and isolated area communities. J. Sustain. Tour. 2002, 10, 191-206. [CrossRef]

33. Fredline, E.; Faulkner, B. Host community reactions: A cluster analysis. Ann. Tour. Res. 2000, 27, 763-784. [CrossRef] 
34. Zhang, J.; Inbakaran, R.J.; Jackson, M.S. Understanding community attitudes towards tourism and host-guest interaction in the urban-rural boader region. Tour. Geogr. 2006, 8, 182-204. [CrossRef]

35. Hardy, A.L.; Beeton, R.J. Sustainable tourism or maintainable tourism: Managing resources for more than average outcomes. J. Sustain. Tour. 2001, 9, 168-192. [CrossRef]

36. Byrd, E.T. Stakeholders in sustainable tourism development and their roles: Applying stakeholder theory to sustainable tourism development. Tour. Rev. 2007, 62, 6-13. [CrossRef]

37. Choi, H.C.; Sirakaya, E. Sustainable indicators for managing community tourism. Tour. Manag. 2006, 27, 1274-1289. [CrossRef]

38. Okazaki, E. A community-based tourism model: Its conception and use. J. Sustain. Tour. 2008, 16, 511-529. [CrossRef]

39. Sebele, L. Community-based tourism ventures, benefits and challenges: Khama Rhino Sanctuary Trust, Central District, Botswana. Tour. Manag. 2010, 31, 136-146. [CrossRef]

40. Jackson, G.; Morpeth, N. Local Agenda 21 and community participation in tourism policy and planning: Future or fallacy. Curr. Issues Tour. 1999, 2, 1-38. [CrossRef]

41. Gross, M.J.; Brown, G. An empirical structural model of tourist and place: Progressing involvement and place attachment into tourism. Tour. Manag. 2008, 29, 1141-1151. [CrossRef]

42. Strzelecka, M.; Beley, B.B.; Woosnam, K.M. Place attachement and empowerment: Do residents need to be attached to be empowered? Ann. Tour. Res. 2017, 66, 61-73. [CrossRef]

43. Anderreck, K.L.; Valentine, K.M.; Knopf, R.C.; Vogt, C.A. Residents' perceptions of community tourism impacts. Ann. Tour. Re. 2005, 32, 1056-1076. [CrossRef]

44. Eslami, S.; Khalifah, Z.; Mardani, A.; Streimikiene, D.; Han, H. Community attachment, tourism impacts, quality of life and residents' support for sustainable tourism development. J. Travel Tour. Mark. 2019, 36, 1061-1079. [CrossRef]

45. Wang, Y.; Yu, Q.; Fensenmaier, D.R. Defining the virtual tourist community: Implications for tourism marketing. Tour. Manag. 2002, 23, 407-417. [CrossRef]

46. Kim, S.; Whitford, M.; Arcodia, C. Development of intangible cultural heritage as a sustainable tourism resource: The intangible cultural heritage practitioners' perspectives. J. Herit. Tour. 2019, 14, 422-435. [CrossRef]

47. Derrett, R. Making sense of how festivals demonstrate a community's sense of place. Event Manag. 2003, 8, 49-58. [CrossRef]

48. Harbor, L.C.; Hunt, C.A. Indigenous tourism and cultural justice in a Tz'utujil Maya community, Guatemala. J. Sustain. Tour. 2021, 29, 214-233. [CrossRef]

49. Buckley, R.; Pickering, C.; Weaver, D.B. Nature-Based Tourism, Environment, and Land Management; CABI Publishing: New York, NY, USA, 2003.

50. Jamal, T.B.; Getz, D. Collaboration theory and community tourism planning. Ann. Tour. Res. 1995, 22, 186-204. [CrossRef]

51. Yates, G.E.; Stein, T.V.; Wyman, M.S. Factors for collaboration in Florida's tourism resources: Shifting gears from participatory planning to community-based management. Landsc. Urban Plan. 2010, 97, 213-220. [CrossRef]

52. Keogh, B. Public participation in community tourism planning. Ann. Tour. Res. 1990, 17, 449-465. [CrossRef]

53. Lewis, A.; Newsome, D. Planning for stingray tourism at Hamelin Bay, Western Austrailia: The importance of stakeholder perspective. Int. J. Tour. Res. 2003, 5, 331-346. [CrossRef]

54. Yankelovich, D. Coming to Public Judgment: Making Democracy Work in a Complex World; Syracuse University Press: Syracuse, NY, USA, 1991.

55. Keske, C.; Smutko, S. Consulting communities: Using audience response system (ARS) technology to assess community preferences for sustainable recreation and tourism development. J. Sustain. Tour. 2010, 18, 951-970. [CrossRef]

56. Peterson, N.A.; Zimmerman, M.A. Beyond the individual: Toward a nomological network of organizational empowerment. Am. J. Community Psychol. 2004, 34, 129-145. [CrossRef] [PubMed]

57. Rappapon, J.M. (Ed.) Studies in Empowerment: Introduction to the Issues; Haworth Press: New York, NY, USA, 1984.

58. Chiang, C.-F.; Jang, S. The antecedents and consequences of psychological empowerment: The case of Taiwan's Hotel Companies. J. Hosp. Tour. Res. 2007, 32, 40-61. [CrossRef]

59. Conger, J.A.; Kanungo, R.N. The empowerment process: Integrating theory and practice. Acad. Manage. Rev. 1988, 13, 471-482. [CrossRef]

60. Speer, P.W.; Peterson, N.A. Psychometric properties of an empowerment scale: Testing cognitive, emotional, and behavioral domains. Soc. Work Res. 2000, 24, 109-118. [CrossRef]

61. Speer, P.W.; Jackson, C.B.; Peterson, N.A. The relationship between social cohesion and empowerment: Support and new implications for theory. Health Educ. Behav. 2001, 28, 716-732. [CrossRef]

62. Tremblay, C.; Gutberlet, J. Empowerment through participation: Assessing the voice of leader from recycling cooperative in Sao Paulo, Brazil. Community Dev. J. 2010, 10, 1-21. [CrossRef]

63. Zimmerman, M.A. Taking aim on empowerment research: On the distinction bwtween individual and pyschological conceptions. Am. J. Community Psychol. 1990, 18, 169-177. [CrossRef]

64. Menon, S.T. Employee empowerment: An integrative psychological approach. Appl. Psychol. 2001, 50, 153-180. [CrossRef]

65. Zimmerman, M.A. Empowerment theory: Psychological, organizational, and community level of analysis. In Handbook of Community Psychology; Rappaport, J., Seidman, A., Eds.; Plenum: New York, NY, USA, 2000; pp. $43-63$.

66. Ohmer, M.L. Citizen Participation in Neighborhood Organizations and Its Relationship to Volunteers' Self- and Collective Efficacy and Sense of Community. Soc. Work Res. 2007, 31, 109-120. [CrossRef] 
67. Peterson, N.A.; Lowe, J.B.; Hughey, J.; Reich, R.B.; Zimmerman, M.A.; Speer, P.W. Measuring the intrapersonal component of psychological empowerment: Confirmatory factor analysis of the sociopolitical control scale. Am. J. Community Psychol. 2006, 38, 287-297. [CrossRef]

68. Leung, L. User-generated content on the Internet: An examination of gratifications, civic engagement and psychological empowerment. New Media Soc. 2009, 11, 1327-1347. [CrossRef]

69. Peterson, N.A.; Lowe, J.B.; Aquilino, L.; Schneider, J.E. Linking social cohesion and gender to intrapersonal and interactional empowerment: Support and new implications for theory. J. Community Psychol. 2005, 33, 233-244. [CrossRef]

70. Peterson, N.A.; Speer, P.W.; Peterson, C.H. Pathways to empowerment in substance abuse prevention: Citizen participation, sense of community, and police responsiveness in an urban U.S. setting. GJCPP 2011, 1, 23-31. [CrossRef]

71. Smith, P.D.; Propst, D.B. Are topic-specific measures of socio-political control justified? Exploring the realm of citizen participation in natural resource decision making. J. Community Psychol. 2001, 29, 179-187. [CrossRef]

72. Zimmerman, M.A.; Rappaport, J. Citizen participation, perceived control, and psychological empowerment. Am. J. Community Psychol. 1988, 16, 725-750. [CrossRef] [PubMed]

73. Peterson, N.A.; Speer, P.W.; Hughey, J. Measuring sense of community: A methodological interpretation of the factor structure debate. J. Community Psychol. 2006, 34, 453-469. [CrossRef]

74. Ungar, M. A constructionist discourse on resilience: Multiple contexts, multiple reality among at-risk children and youth. Youth Soc. 2004, 35, 341-365. [CrossRef]

75. Diemer, M.A.; Blustein, D.L. Critical consciousness and career development among urban youth. J. Vocat. Behav. 2006, 68, 220-232. [CrossRef]

76. Markward, M.; Mateeva, A.; Markova, T.; Petrov, R.; Markova, G.; Chemova, A. Sociopolitical control among parents of socio-age children in a post-socialist city. Int. J. Soc. Welf. 2006, 15, 84-89. [CrossRef]

77. Hechanova, M.R.; Alampay, R.B.A.; Franco, E.P. Psychological empowerment, job satisfaction and performance among Filipino service workers. Asian J. Soc. Psychol. 2006, 9, 72-78. [CrossRef]

78. Anderreck, K.; Vogt, C.A. The relationship between residents' attitudes toward tourism and tourism development options. J. Travel Res. 2000, 39, 27-36. [CrossRef]

79. Ko, D.; Stewart, W.P. A structural equation model of residents' attitudes for tourism development. Tour. Manag. 2002, 23, 521-530. [CrossRef]

80. Wang, Y.; Pfister, R.E. Residents' attitudes toward tourism and perceived personal benefit in a rural community. J. Travel Res. 2008, 47, 84-93. [CrossRef]

81. Woosnam, K.M.; Norman, W.C. Using emotional solidarity to explain residents' attitudes about tourism and tourism Development. J. Travel Res. 2012, 51, 315-327. [CrossRef]

82. Dillman, D.A.; Smyth, J.D.; Christian, L.M. Internet, Mail, and Mixed-Mode Surveys: The Tailed Design Method, 3rd ed.; John Wiley \& Sons: Hoboken, NJ, USA, 2009.

83. Flower, F.J. Improving Survey Questions: Design and Evaluation; SAGE Publications: Thousand Oaks, CA, USA, 1995.

84. Churchill, G.A. A paradigm for developing better measures of marketing constructs. J. Mark. Res. 1979, 16, 64-73. [CrossRef]

85. Hung, K.; Sirakaya-Turk, E.; Ingram, L.J. Testing the efficacy of an integrative model for community participation. J. Travel Res. 2011, 50, 276-288. [CrossRef]

86. Lankford, S.V.; Howard, D.R. Development a tourism impact attitude scale. Ann. Tour. Res. 1994, 21, 121-139. [CrossRef]

87. Mason, P.; Cheyne, J. Residents' attitudes to proposed tourism development. Ann. Tour. Res. 2000, 27, 391-411. [CrossRef]

88. Kraus, R.; Allen, L. Research and Evaluation in Recreation, Parks, and Leisure Studies; Publishing Horizon Inc.: Worthington, OH, USA, 1987.

89. Peterson, N.A.; Peterson, C.H.; Agre, L.; Christens, B.D.; Morton, C.M. Measuring youth empowerment: Validation of a sociopolitical control for youth in an urban community context. J. Community Psychol. 2011, 39, 592-605. [CrossRef]

90. Martínez, M.L.; Loyola, L.I.; Cumsille, P. Quality of participation in youth organizations: Relationships with identity and sense of sociopolitical control. Youth Soc. 2017, 49, 968-993. [CrossRef]

91. Opara, I.; Rodas, E.I.R.; Lardier, D.T.; Garcia-Reid, P.; Reid, R.J. Validation of the abbreviated socio-political control scale for youth (SPCS-Y) among urban girls of color. Child Adolesc. Soc. Work J. 2020, 37, 83-95. [CrossRef] [PubMed]

92. Jeong, E.; Ryu, I.; Brown, A. Moderating effect of sense of community on the relationship between psychological empowerment and tourism policy participation of local residents. Glob. Bus. Financ. Rev. 2018, 23, 36-46. [CrossRef]

93. Yuksel, A.; Yuksel, F.; Bilim, Y. Destination attachment: Effects on customer satisfaction and cognitive, affective and conative loyalty. Tour. Manag. 2010, 31, 274-284. [CrossRef]

94. Garver, M.S.; Mentzer, J.T. Logistics research methods: Employing structural equation modeling to test for construct validity. J. Bus. Logist. 1999, 20, 33-57.

95. Lundberg, J. Lifting the crown-citation z-score. J. Informetr. 2007, 1, 145-154. [CrossRef]

96. Babbie, E. The Practice of Social Science, 9th ed.; WadsworthWadsworth Thomson Learning: Belmont, CA, USA, 2001.

97. Hepper, P.P.; Hepper, M.J. Writing and Publishing Your Thesis, Dissertation E Research: A Guide for Students in the Helping Professions; Thomson: Belmont, CA, USA, 2004.

98. Cronbach, L.J. My current thoughts on coefficient alpha and successor procedures. Educ. Psychol. Meas. 2004, 64, 391-418. [CrossRef] 
99. Vaske, J.J. Survey Research and Analysis: Applications in Parks, Recreation and Human Dimensions; Venture Publishing Inc.: State College, PA, USA, 2008.

100. Kline, R.B. Principles and Practice of Structural Equation Modeling, 2nd ed.; The Guildford Press: New York, NY, USA, 2005.

101. Chu, K.H.; Murrman, S.K. Development and validation of the hospitality emotional labor scale. Tour. Manag. 2006, $27,1181-1191$. [CrossRef]

102. Dunn, S.C.; Seaker, R.F.; Waller, M.A. Latent variables in business logistics research: Scale development and validation. J. Bus. Logist. 1994, 15, 145-172.

103. Wang, Y. Assessment of learner satisfaction with asynchronous electronic learning systems. Inf. Manag. 2003, 41, 75-86. [CrossRef]

104. Dimitrov, D.M. Statistical Methods for Validation of Assessment Scale Data in Counseling and Related Fields; American Counseling Association: Alexandria, VA, USA, 2012.

105. Harrington, D. Confirmatory Factor Analysis; Oxford University Press: Oxford, UK, 2009.

106. Andrew, D.P.S.; Pedersen, P.M.; McEvoy, C.D. Research Methods and Design in Sport Management, 2nd ed.; Human Kinetics: Champaign, IL, USA, 2011.

107. Carmines, E.G.; McIver, J.P. Analyzing models with unobserved variables: Analysis of covariance structures. In Social Measurement: Current Issues; Bohrnstedt, G., Borgatta, E., Eds.; Sage: Beverly Hills, CA, USA, 1981; pp. 65-115.

108. Jőreskog, K.G.; Sőbom, D. LISREL-VI User's Guide, 3rd ed.; Scientific Software: Mooresville, NC, USA, 1984.

109. Hoe, S.L. Issues and procedures in adopting structural equation modeling techique. JAQM 2008, 3, 76-83.

110. Schilling, M.A. Technology success and failure in winter-take-all markets: The impact of learning orientation, timing, and network externalities. Acad. Manag. J. 2002, 45, 387-398.

111. Raykov, T. Introduction to structural equation modeling. In STAT Workshop Series; Michigan State University: East Lansing, MI, USA, 2008.

112. Browne, M.W.; Cudeck, R. Alternative ways of assessing model fit. In Testing Structural Equation Models; Bollen, K., Long, J., Eds.; Sage: Newbury Park, CA, USA, 1993; pp. 136-162.

113. Yoon, Y.; Uysal, M. An examination of the effects of motivation and satisfaction on destination loyalty: A structural model. Tour. Manag. 2005, 26, 45-56. [CrossRef]

114. Jeong, E.S. Importance of Sociopolitical Control, Sense of Community and Citizen Participation in Tourism Promotion and Policy. Ph.D. Thesis, Michigan State University, East Lansing, MI, USA, 2012.

115. Throndike, R.M.; Throndike-Christ, T. Measurement and Evaluation in Psycholoty and Education, 8th ed.; Pearson: Boston, MA, USA, 2010.

116. Fornell, C.; Larker, D.F. Evaluating structural equation models with unobervable variables and measurement error. J. Mark. Res. 1981, 18, 39-50. [CrossRef]

117. Said, H.; Badru, B.B.; Shahid, M. Confirmatory factor analysis (CFA) for testing validity and reliability instrument in the study of education. Aust. J. Basic Appl. Sci. 2011, 5, 1098-1103. 